\title{
Kurmaca ile Gerçeklik Arasında Bir Yazar: Ahmet Mithat Efendi
}

\author{
Muhittin DOĞAN*
}

\section{$\ddot{O} z$}

Osmanlının kendi dışındaki dünyaları tanıma girişimleri Gazavatnamelerle, yabancı diyarlara esir düşenlerin anı ve mektuplarıyla başlayıp sefaretname ve seyahatnamelerle devam eder. Ana işlevlerinden birisi de doğduğu toplumların yaşamlarına ayna tutmak olan roman türü, Tanzimat'la birlikte yeni bir görev üstlenerek, Osmanlı halkının Batıya açılan pencerelerinden birisi olur. Başlangıçta çoğu Osmanlı yazarı, romanlar sayesinde hem halkı eğitmeyi hem de Batılı hayatı onlara tanıtmayı amaçlarlar.

$\mathrm{Bu}$ yazarlardan birisi de edebiyatın her alanında eserler veren Ahmet Mithat Efendi'dir. Edebiyatın asıl amacının halkı eğitmek olduğuna inanan yazar, Paris’i hiç görmeden yazdığı Paris 'te bir Türk adlı romanı ve uzunca bir Avrupa yolculuğuna çıkarak oluşturduğu Avrupa'da Bir Cevelan adlı seyahatnamesinde, Osmanlı okuyucusu için geniş bir Avrupa penceresi açmaya çalışır. Aynı amaçlar için yazılmış her iki eserde de birçok ortak nokta olduğu okuyucunun gözünden kaçmaz. Her iki eserde de yazar, Osmanlı kültürünün yılmaz bir savunucusudur, ilerlemiş Avrupa medeniyetinden ülkesine faydalı olacağına inandığı bütün yenilikler hakkında bilgi edinmek ve onları ülkesinde tanıtmak gayesinden hiç vazgeçmez.

Anahtar Kelimeler: Seyahatname, roman, Ahmet Mithat Efendi, Osmanl, Avrupa, Paris.

* Dr. Öğr. Üyesi, Afyon Kocatepe Üniversitesi, Fen Edebiyat Fakültesi, Türk Dili ve Edebiyatı Bölümü. Afyon. Türkiye. Elmek: dogan.muhittin@hotmail.com https://orcid.org/0000-0002-3525-5981 


\title{
An Author Between Fiction and Reality: Ahmet Mithat Efendi
}

\begin{abstract}
For the Ottomans, attempts to know the outer world begin with the gazavatnames, memoirs and letters of captives held in foreign countries and go on with the sefaretnames and seyahatnames. One of the main functions of the novel is to reflect the lives of the communities in which it was born. With the Tanzimat the novel undertakes another mission and it becomes one of the windows opening to the West for the Ottomans. Initially, many Ottoman authors aim both to educate the people and to introduce them the Western life by means of the novels.

One of those authors is Ahmet Mithat Efendi, who had works in various fields of literature. The author, believing that the primary aim of literature is to educate people, tries to open up a wide window into Europe for the Ottoman readers with his novel Paris 'te Bir Türk, which he wrote without having ever been to Paris himself before and his seyahatname titled Avrupa'da Bir Cevelan, which he wrote during his long trip around Europe. Readers notice several commonalities in both novels that were written for the same purposes. In both works, he is a dauntless advocate of the Ottoman culture, and he never gives up on his purpose of gathering information about all innovations of the European civilization which he thinks will be beneficial for his country and of promoting them to his country.
\end{abstract}

Keywords: Seyahatname (Travelogue), novel, Ahmet Mithat Efendi, Ottomans, Europe, Paris 


\section{Extended Summary}

For the Ottomans, attempts to know the outer world begin with the gazavatnames, memoirs and letters of captives held in foreign countries and go on with the sefaretnames and seyahatnames. One of the main functions of the novel is to reflect the lives of the communities in which it was born. With the Tanzimat the novel undertakes another mission and it becomes one of the windows opening to the West for the Ottomans. Initially, many Ottoman authors aim both to educate the people and to introduce them the Western life by means of the novels.

In seyahatnames creating an awareness by showing the gap between the two worlds realistically is the main goal. This goal is also followed in the novels with the help of fictional imagination.

Ahmet Mithat Efendi, who prioritizes social benefits in all his artistic works and initiatives, especially in his novels tries to open the doors of a new world to the society. For this sake, he leaves aside artistic selectivity and creative anxiety, without even thinking that his artistic skills can be roughly criticized by his opponents.

"Paris 'te Bir Türk" and "Avrupa'da Bir Cevelan" are two works of the author written to promote Europe to the society. These two works are quite similar. One of these two works is a novel and the other one is a travelogue. Both of them takes the reader to a walk around the city of Paris, but as for the novel, the author had never been in Paris before when he wrote it.

Ahmet Mithat Efendi builds his novel titled "Paris'te Bir Türk" on female characters except a male character named Nasuh, who is a representative of the writer himself. All the male characters in the novel fades away in front of the knowledgeable, gentle, calm, and intellectual Nasuh Efendi's figure. Nasuh is the shining star of the novel. Almost all the main male characters are in need of him. Because Nasuh Efendi has a strong personality, he is a problem solver, he has logical solutions to everything even for love affairs of the others. Idealized character of Nasuh seems unrealistic and superhuman being from the epics and fairytales than a simple novel character. 
Ahmet Mithat Efendi tries to highlight the features of an Ottoman gentlemen which can be appreciated by foreigners at every opportunity he finds. In both works, he depicts himself and the Nasuh as a courageous and benevolent person. For example, in his work "Avrupa'da Bir Cevelan", he is the first one who gives a first aid to a girl who faints on the ferry while the others do not care. In his novel, "Paris'te Bir Türk", there is an Englishman who is in danger of drowning with his horse in the lake while everybody is watching with fun laughters, only Nasuh jumps into the lake without even thinking that his clothes will be ruined and rescues the distraught man.

Another topic that occupies the author's mind is the misconception about the Ottomans in Europe. In his works he claims that the reason for this is the funny and unrealistic works of some travel writers and painters to gain more attention. The author himself expresses his discomfort about these mistakes at every opportunity. His fictional character Nasuh Efendi also does not hesitate to enter into long debates in order to improve the image of the Ottomans and the city of Istanbul. And he strongly claims that there have been many deep-rooted developments in the Empire and Istanbul, which were in close contact with Europe for a long time.

Ahmet Mithat, just like the other Tanzimat writers, compares the Ottoman society with the Western society. In his novel Nasuh Efendi and in the travelogue the author himself always takes the role of volunteered advocacy of his society. He states in a convincing manner that in spite of the financial advance of the West, in a spiritual way, the Ottoman world has many good or even better aspects.

Due to the overwhelming similarities, it would not be wrong if we say the novel character Nasuh Efendi and the travel writer Ahmet Mithat are the same person. We can also say that the fictional character of Nasuh Efendi is more idealized and perfected than the real personality of the author. 


\section{Giriş}

Muktedir olmanın verdiği özgüvenle küçümsenen insanların topluluğu olan Avrupa -birlikte olamasa bile- Osmanlının İstanbul'un fethiyle yan yana yaşamak zorunda olduğu bir coğrafi mekân haline gelir. Osmanlı, kendi dışında var olan “öteki”yle ilgili malumatları da seyahatnamelerin ilk örneği kabul edilen Gazavatnameler sayesinde elde etmeye çalışır. Asıl amaçları sınır boylarındaki akıncılara kahramanlık duygusu vererek, onların daha yürekli savaşmalarını sağlamak olan bu metinlerde, düşmanla ilgili; "korkak, pısırlk, savaş meydanlarından kaçan, Müslümanlara karşı her zaman şeytanca düşünceler içerisinde olan insanlar..." (Şirin, 2009: 56-57) gibi kalıplaşmış bilgilere bolca rastlanılır.

Erken Osmanlı döneminde, Gazavatnamelerin yanında, Hıristiyan dünyaya esir düşen Müslümanların hatıraları, mektupları, özellikle de Cem Sultanın Avrupa'daki hayatını anlatan Haydar Çelebi'nin yazdığı Vakı'at-ı Sultan Cem gibi eserler, Osmanlının etrafındaki coğrafyalara açılan gözleri olur. Sefaretnameler, seyahatnameler ve roman gibi edebi türler de zamanla tanıma işinin hızlanmasına önemli katkılar sağlar. Bu çalışmada edebiyatın çeşitli alanlarında eser veren Ahmet Mithat'in Avrupa'da Bir Cevelan (1889) adli seyahatnamesi ile Paris'i görmeden yazdığı Paris’te Bir Türk (1876) romanı üzerinde durularak iki eser arasındaki benzerliklere dikkat çekilecektir.

\section{Avrupa'yı Tanıma Girişimleri}

Dört yüz yıla yakın bir süre devam eden bir dünya hâkimiyetinin vermiş olduğu kendine aşırı güven duygusuyla rahatlayan ve kaygısız bir hayat yaşayan Devlet-i Aliye, özellikle 16. yüzyılın ortalarından itibaren askeri, ilmi ve iktisadi sahalarda, kurumlarının nasıl bozulduğunun farkına varamaz ve bunların acilen düzeltilmeleri gerektiğini de zamanı geçmeden anlayamaz (Korkmaz, 2012: 1617). İçine kapanma, cenneti öteki dünyada arama, başarısızlıklarla yüz yüze kalınca tarihsel bir nostaljiye sarılma -özellikle Kanuni dönemine aşırı önem verme- dünyanın sonunun geldiğine inanma gibi tutumlar da bu sendromun tipik özelliklerinden olur. 
Osmanlının kendi dışındaki dünyaya bakışı, tarihsel süreçlere ve yaşanan olaylara -daha doğrusu kaybedilen savaşlara- bağlı olarak değişimler gösterir. İlk büyük kırılma/sarsıntı Karlofça Antlaşmasıyla başlar. Bu zamana kadar kendisini dünyanın merkezinde, üstün ve yenilmez bir güç olarak gören (Koçak, 2013: 471), kendi dışındaki dünyayı da korkakların dünyası olarak algıladığı için küçümseyen Osmanlının özgüveni sarsılmaya başlar. Kaybedilen topraklardan ziyade; yenilmezliğine inandıkları İmparatorluğun imajının kaybolması endişe vericidir, onlar için. Öte yandan tarihsel prangalarından kurtulan, yaşadıkları dünyayı yeryüzü cenneti yapmayı amaçlayan Avrupa, girdiği büyük değişim hareketi içerisinden güçlenerek çıkma yolundadır. Sanayi devrimi, düzenli ordu, güvenilir idare sistemleri ile onlar, geleneksel düşmanları olan Osmanlının karşısına yeni ve güçlü bir yapıyla dikilir. Gelişmelerin doğal sonucu olarak; bir zamanlar güç yetiremedikleri, üzerlerine sürekli akınlar yapan bir milletin ordularını, kolayca saf dışı edebilmenin verdiği gurur/özgüven artık onların hanelerine yazılmaya başlar. Yenilgilerin sarsıcı etkisi ile Osmanlı, biraz geç de olsa karşısındaki Batı'nın eski Batı olmadığını anlar. Askeri alanlarda karşılaşılan peş peşe olumsuzluklardan dolayı Osmanlı, yapılacak "1slahatlarla" her şeyin düzelebileceğine inanır. Fakat ekonomide, mali ve sosyal yapıda köklü değişiklikler yapmayı, çağı ve çağın getirdiği teknolojiye ayak uydurabilme düşüncelerini, önceleri pek akıllarına getiremez (Bardakçı, 2015: 57).

Osmanlıyı derin uykusundan uyandırmak için ilk defa iki dikkat çekici adım atılır: Bunlardan birincisi Avrupa'nın nasıl bir büyüyen tehlike olduğunu Müslüman halka haber verip, onları uyandırmak amacıyla kaleme alınan Kâtip Çelebi’nin Irşad-ül Hayara adlı eseridir. Çelebi, eserinde, Müslümanların tembellik içerisinde ve çevrelerinde dönen dolaplardan habersiz olduklarını, Avrupa'nın ise nüfusunun hızla arttığını, ilerleyen gemicilikleri sayesinde bütün dünyayı zapt etme emelinde büyük, tehlikeli bir güce dönüştüklerini, açık açık haber verir; ikinci önemli adım ise İbrahim Müteferrika'nın yazdığı Usulü'l Hikem fi Nizami’l Ümem adlı kitabıdır (Şirin, 2009:116-117). Bu eserde, Müteferrika, askeri düzeniyle, keşifleriyle, sanayisi ile hızlı bir şekilde gelişip güçlenen ve Osmanlı için büyük bir tehlike olmaya başlayan Avrupa'ya karşı Osmanlıyı haberdar etmeye/uyarmaya çalışır.

III. Selim döneminin başlamasıyla Osmanlı, içinde bulunduğu çıkmazdan kurtulma yolunun Batıya yönelmekten geçtiğini kesin olarak anlar. Kâtip Çele- 
bi ve İbrahim Müteferrika'nın etkilerinin yavaş yavaş kendisini göstermesiyle Osmanlı dünyası, Cumhuriyete kadar devam edecek bir yenileşme (Batılılaşma) sürecinin içerisine -bazen kesintilere uğrasa da- kendisini isteyerek veya istemeyerek birakmak zorunda kalır:

“Türk Devrimi, şekli anlamda, 1908'de eski bir siyasal düzenin zorla atılması ve yenisinin kurulmasıyla başladı. Fakat bir diğer anlamda, iki yüzylldan beri sürmekte bulunmuştur. Bir zamanlar adam yerine konmayan düşmanlar elinde bir dizi yenilgiler, Türkleri, varlıklarını korumak için, Avrupa silahlarını benimsemek, Avrupalı danışmanlar çă̆ırmak ve böylece ne kadar isteksizce olursa olsun, modern devlet ve ordunun temelinde yatan yeni fikirleri ve kurumları kabul etmek zorunda biraktığ zaman başladı. İlk reformlar, sadece daha iyi ordular ĕgitmek ve donatmak peşinde olan otokratik hükümdarların eseriydiler" (Lewis, 1988: 473).

Büyüklüğüne/azametine yakıştıramadığı için yabancı ülkelerde elçilikler bulundurmayan Devlet-i Aliye, geleneğinden vazgeçerek Damat İbrahim Paşa döneminde, Avrupa ülkelerine elçiler gönderir. Londra, Paris, Viyana, Berlin ve Petersburg gibi önemli merkezlerde oluşturulan elçilikler sayesinde, Osmanlı için geniş bir Avrupa penceresi açılır, yeni medeniyeti daha rahat temaşa edebilecekleri. Avrupa kültürüyle ilk karşılaşan Osmanlı seçkinleri, bir zihniyet değişikliğinin içerisinde kendilerini bulur ve -bilerek veya bilmeyerekyakın tarihte yaşanılacak büyük toplumsal değişimlerin hazırlayıcıları olurlar (Hanioğlu, 1992:149), (Dayanç, 2016:40).

18. yüzyıl Osmanlı aydınlarının/devlet yetkililerinin Rusya’yı, özellikle de Avrupa'yı çok dikkatli şekilde gözlemleyip sonra da değerlendirmelerini yazıya döktükleri bir dönemdir. Karşılarındaki yeni dünyayı sadece savaş meydanlarında tanımaktan vazgeçip, yaşantılarıyla görmeye çalışırlar (Ortaylı, 2006: 16). Osmanlı elçileri Sefaretnameler' ${ }^{2}$ aracılı̆̆ıyla gittikleri ül-

\footnotetext{
1 Sefaretnamelerin Osmanlı toplumundaki işlevlerine M. Fatih Andı, Bir Osmanlı Bürokratının Avrupa İzlenimleri adlı eserinde dikkat çeker. Ona göre "Sefaretnameler XVII. yüzyılın sonundan itibaren yazılmaya başlanmıştır. Fakat bilhassa Sultan III. Selim’in Avrupada daimi ikamet elçilikleri açmasından sonra, gelişen ve hızlanan Osmanlı-Avrupa siyasi ilişkileri neticesinde XVIII. ve XIX. asırda Avrupa’nın daha fazla ülkesinde, daha çok sefirin görevlendirilmesiyle birlikte, bu son iki yüzyılda sayıca daha fazla sefaretname yazıldığına şahit oluruz.

Sefaretnamelerin bazıları resmi raporlar şeklinde iken, bazıları da sefarette görevli bürokratların memlekete dönmesinden sonra kaleme aldığı seyahat notları yahut izlenimleri ve bu izlenimleri etrafında edindiği düşünceleri aktaran risaleler şeklinde yazılmıștır.
} 
keleri, dönemine göre oldukça sade bir dille (Ortaylı, 2016: 137), çok yönlü tanıtma gayretleri içerisindedirler. Sefaretnamelerin içerisinde en meşhuru ve Osmanlıya Avrupalılaşma yolunda aydınlatıcı olacak olanı, 18. yüzyılın ilk yarısında, Paris'e elçi olarak gönderilen Yirmisekiz Çelebi Mehmed'in kaleme aldığı Paris Sefaretnamesi'dir. Elçinin Fransa'ya gidişinin etkileri, Osmanlı toplumundan önce Fransa toplumunda görülür. Müslüman Türk’ün hayallerdeki masalsı yaşantısına duyulan özlemin katkılarıyla Fransa'da Türk modası (turqia) yayılmaya başlar. Paris'in elitleri evlerinin bir köşesine kurdukları Şark köşelerinde/Şark odalarında, Şark'ın gizemli hayatının izlerini bulmaya çalışırlar. Ancak çok güzel başlayan bu Türk modası, Osmanlı'nın sürekli güç ve imaj kaybetmesinden daha ileri boyutlara taşınarak uzun ömürlü olabilme şansını yakalayamaz: ${ }^{2}$

"Batı'nın gözünde geriye kalan, aşağılayıcı, alaycı yorumlarla birlikte hayal kırıkliğl ve de elbette Osmanlı Imparatorluğunu daha açıkça sömürgeleştirme stratejileridir. Bir zamanlar Doğu'nun simgesi olan Türkiye, öznenin bilinçdışı bileşeni olan bir Öteki olmaktan çıkmış, Batı'da kurtarıcısını ve koruyucusunu arayan sefil (abject) bir zavallyya dönüşmüştür" (Gürsoy,2008:202).

Bakmayı ve görmeyi bilen bir Osmanlı bürokratının kaleminden çıkan Sefaretname' de Fransa'nın ilerlemiş birçok yönüne dikkat çekilmeye çalışılır. Bu küçük kitabın modernleşme tarihimizdeki yeri Tanpınar'a göre büyük olacaktır:

“Hiçbir kitap Garplılaşma tarihimizde bu küçük 'Sefaretname' kadar mühim bir yer tutmaz. Okuyucu üzerinde 'Binbir Gece'ye iklim ve mahiyet değiştirmiş hissini bırakan bu kitabın hemen her satırında gizli bir mukayese fikrinin beraberce yürüdüğü görülür. Hakikatte bu sefaretnamede bütün bir programlar gizlidir." (Tanpınar, 1985: 44).

\footnotetext{
Her üç şekliyle de bu eserler Türk siyasi tarihi ve Osmanlı diplomasisi için zengin bilgi veren vazgeçilmez kaynaklardır." (bkz. M. Fatih And, Bir Osmanl Bürokratınin Avrupa İzlenimleri, Kitabevi, 1996, s. 7.

2 Bu doğrultuda Ranna Kabbani, "Osmanlı tehdidi azalarak, geriye yalnızca bir güvensizlik ortamı kaldığında, Hıristiyan Batı ile Müslüman Doğu arasındaki düşmanlık da gerilemişti. Ancak, bu değişikliğin sağladığı politik tavırdan sonra Doğunun edebi anlamda uydurulanlarla kullanımı son buldu; Doğu Batının düşlerindeki yerini ve değerini artık yitirmişti. Doğu, Batılı güçlerin hâkimiyetine daha fazla girdikçe, daha açık olarak düşlerden, edebiyattan, resimden ve modadan çekildi." diyerek görüşlerini dile getirir. (bkz. Rana Kabbani, Avrupa’nın Doğu İmajı, Bağlam, 1993, s. 164.)
} 
Bahsi geçen eser sayesinde, müşahede edilen Fransız hayatı, özellikle de Paris’te oluşturulan modern kültür, Osmanlı için örnek alınması ve ulaşılması gereken son noktadır. Batı medeniyetinin adeta bir tahlili olan (Ortayl1, 2016:140) Çelebi'nin Sefaretnamesi sayesinde Osmanlı, yenilenme ve modernleşme yolunda büyük adımlar atmaya başlar. İlaveten parklar, bahçeler, bunların düzenlenmesi sarayların süslenmesi gibi Avrupai tarzda dekoratif işlere girişilir (Hourani, 1993: 140-141). Toplumsal hayatımızda bir müsamaha dönemi göze çarpar, buna paralel olarak Avrupalı sanatçıların, Avrupai tarzda yaşama adapte olmuş gayrimüslimlerin İstanbul'da ve saray çevresinde daha fazla görünür olmaları da dikkat çekicidir. Adına "Lale Devri" denilen zevkli bir yaşam tarzı başlatılır. Yalnız bu tarz, Patrona Halil isyanıyla son bulur. Fakat yenileşme hareketleri içerisinde önemli bir adım atılır. O da Yirmisekiz Mehmet Çelebinin de desteğiyle İbrahim Müteferrika'nın matbaayı Osmanlı kültür hayatına kazandırmış olmasıdır (1727). Dini eserlerin basılmama şartı ile de olsa matbaanın Osmanlıya gelmesi, Batılılaşma yolunda geç de olsa atılmış çok büyük bir adımdır. Müteferrika bastığı eserlerle Osmanlının Garplılaşma sürecine hız vermeye çalışır bir gayret içerisindedir. Özellikle yazdığg Usulü'lhikem fi nizamü'l-ümem adlı eseri: 'Bizde Avrupalılaşma hareketinin beyannamesi addedilmesi lazım gelen Müteferrika 'nın en önemli eseridir' (Tanpınar, 1985:46).

Sefaretnamelerle başlayan Osmanlı'nın Avrupa'yı tanıma girişimleri, Seyahatnameler sayesinde sınırları ve boyutları genişleyerek yeni zeminler bulur. Önceleri kendi coğrafyalarına ve Asya-Afrika bölgelerine doğru az da olsa yapılan seyahatler, Osmanlı'nın yönünü Batıya ve Batılılaşmaya çevirmesiyle, seyyahlar da doğal olarak rotalarını Batı'ya döndürürler. 19. yüzyılda Avrupa üzerine yazılmış seyahatnamelerin sayısında o zamana kadar görülmemiş bir artış göze çarpar³. İlk sefaretnamelerimiz, bizlere genelde Fransa’yı merkez alan Batıyı tanıtmaya çalışırken seyahatnameler ise Fransa'yla birlikte diğer Avrupa ülkelerinin ve başkentlerinin kapılarını da açar, coğrafi olarak çok yakınlarında olmalarına rağmen asırlardır onların uzağındaymış gibi yaşayan Osmanlı elitlerine. Seyyahların eserleriyle ve yanlarında getirdikleri Avrupai

3 Bu alanda geniş bilgi için Baki Asiltürk’ün çalışmalarına bakılabilir ( Asiltürk, B. (2000), Osmanlı Seyyahlarının Gözüyle Avrupa, Kaknüs, İstanbul.) 
eşyalar sayesinde açılan bu yeni, geniş pencereler, Osmanlı ülkelerine taşınan Batı kültürü ve yaşam tarzı, zengin tabakalarda karşılığını bularak alafranga bir yaşam modası başlatmaya muvaffak olur.

Avrupa'ya giden hemen bütün seyyahlar, içine düştükleri/girdikler yeni modern dünya karşısında, bir şok yaşayacaklardır; onların benliklerinde, iç dünyalarında etkileri şiddetli olan bir şok. Diyar-1 küfrün mamur, şaşalı beldelerine karşılık, mülk-i İslam'ın içler acısı hallerinin verdiği sancıların şiddeti de kolay geçmez. Avrupa'nın gelişmişliği karşısında şaşkına dönen Osmanlı kalem erbabı, vatana/millete hizmet düşüncesiyle gördüklerini kalemleri aracılığıyla ülkelerine taşıyarak halkı aydınlatmayı, kendilerine bir borç bilirler. Böyle bir amaç, Oryantalistler Kongresi için İstanbul'dan Stockholm'e yolculuğa çıkan Ahmet Mithat Efendi'nin kaleme aldığ1 seyahatnamesinde de gözlemlenir. Yazarın bin sayfadan fazla bir yekûn tutan Avrupa'da Bir Cevelan adlı eserinde, onun birincil amacının Avrupa'daki terakkiyi bütün yönleriyle kavrayarak, ülkesine taşıyabilmek olduğu gözlerden kaçmaz. Cevelan'ın her satırında vatanına hizmet etme heyecanı hiç eksilmeyen bir Osmanlı aydınının, ülkesinin gelişmesi için çırpındığına şahit olunur. Bu istemle koca muharrir, bazen bir tuğla fabrikasında, bazen bir çiftlikte; bazen bir kütüphanede veya müzededir, ülkesinin terakkisi için ne bulursa bu gelişmiş mekânlardan taşıyabilmek amacıyla. Aynı amaca yazarın ortaya koyduğu diğer edebi türlerde de fazlasıyla şahit olunur; özellikle roman yazar için vazgeçilmez bir irşat vasıtasıdır.

\section{Batıya açılan yeni bir pencere: roman}

Don Kişot'la başlayıp çeşitli değişimlerin/dönüşümlerin yanı sıra klasizm, romantizm realizm, modernizm ve postmodernizm akımlarının şekillendirmelerinden de geçerek günümüze kadar -bazen popülaritesi azalarak; bazen ise altın çağlarını yaşayarak- gelen roman türü, insanoğlunun yaşamında büyük değişikliklerin olduğu ve madde egemenliğinin dorukta yaşandığı (Ecevit, 2006:25) on dokuzuncu yüzyılla birlikte içinden çıktığı toplumun yaşantılarına 1şık tutan en önemli edebi faaliyet olarak yazın hayatında yerini alır:

"Roman gerçeklerle dolu hakikatsiz hikâye. Büyüden arındırılmış dünyanın trajik destanı. Büyüsüz dünya, yeni aklın hurafesi. Roman, bu dünyaya ses veriyor. Ses değil, çı̆̆llk. Sarslyor ve cezbediyor" (Özel, 2018:11) 
Temelleri daha önceki asırlarda atılan Batıdaki sanayi devrimi, on dokuzuncu yüzyılda kendisini daha fazla hissettirmeye başlar. Artık dünyada, fazlasıyla gelişmiş/sanayileşmiş bir Batı; diğer tarafta ise bu gelişmenin parıltısı karşısında şaşkına dönmüş toplumlar vardır. Gelişen yeni cazibe merkezinden nasiplenmek isteyen milletlerin ilgisi, demografik alt üst oluşları da içinde barındıran ciddi değişimlere kapı aralamaktadır (Berman, 2017:28). Edebiyatta da kendisini göstermeye başlayan Batılılaşma/modernleşme arzusu, tiyatro ve roman gibi iki edebi türün "topluma dokunmada, onu istenildiği gibi yönlendirmede, ĕgitmede" daha etkili olacağına inanılmasıyla Osmanlı ediplerinin önüne rahatlıkla kalem oynatacakları geniş bir alan açılmış olur. Zaman içerisinde roman, kendisine daha konforlu zeminler bularak okuyucusunun karşısına çıkar. Birincil görevlerinin toplumu edebi eserler aracılığıyla eğitmek olduğuna inanan Tanzimat yazarları, geniş halk kitlelerinin kolay kabul edemeyeceği (And1, 2013:19) yeni bir dünya ve insan tiplemesi sunmaya çalışır. Sunulan kahramanın ana özelliği de şüphesiz Batılı kaynaklardan beslenmiş, yeni tip bir kahraman olmasıdır; çünkü Osmanlı geçmişinde, Batılı tarzlarıyla kıyaslanacak gerçeklikte anlatı geleneği de henüz oluşmamıştı (Belge, 1994:17). Romanlarda ortaya çıkan yeni kişilikler; Doğuya ve onun değerlerine fazla ilgi göstermeyen, aydınlanmanın Batıdan geleceğine inanılarak hareket ettirilen ve medeniyet değiştirme yolunda yazarın en önemli destekçisi, kurmaca kahramanlardır, artık. Oluşturulmak istenilen yeni toplumda yer almasını istemediği eski anlayışı çağrıştıran tipler de bu süreçte acımasızca eleştirilmekten kendilerini kurtaramazlar. Böylece sokağa tutulan bir ayna görevini üstlenen roman, bu görevinden uzaklaşarak, sokağın önünden gitmeyi, onu yeniden şekillendirmeyi amaçlayan bir türe de evrilmiş olur, toplumcu yazarların elinde (Balcı, 2010:286-287).

Roman yazarlarının, Tanzimat'tan Cumhuriyet'e uzanan süreçte, ana kahramanları arasından hep roman okuyan karakterler karşımıza çıkar ve bu şahıslar okudukları romanlar sayesinde hayatları alt üst olan kişilerdir; ama bozulan hayatlarını düzeltmek veya kendilerine yeni bir yol çizebilmek için de yine romanların sayfalarında ararlar kurtuluşlarını:

İlk örnekler A. Mithat'tan: Müşahedat'ta küçük yaşta anasız babasız kalan Agavni, hayatı okuduğu romanlardan öğrenir; romanların da etkisiyle sefih bir 
hayatı seçer. Bahtiyarlık adlı uzun hikâyede bu kez Nusret Hanım romanların etkisiyle hayalle hakikati karıştırıp yanlış adamı koca seçer. Jön Türk teyse okuduğu kitaplar yüzünden bir ifrat-kadına dönüşen, sonunda da canına kayan frenkmeşrep Ceylan çıkacaktır karşımıza. Örnekler Ahmet Mithat'la sinırlı değil. Nabizade Nazım 'n Zehra sında Zehra da aşkı romanlardan öğrenir (Gürbilek, 2017:275).

Medeniyet buhranının çocuklarından biri olan A. Mithat Efendi, modern Avrupa'nın yeniliklerinin uzağında kalmayarak onların kendi ülkesinde de hızlı bir şekilde neşvünema edebilmesi için çalışırken (Tanpınar, 1985:472) edebiyatın her nev'inde eserler ortaya koymaktan geri durmaz ${ }^{4}$. Bu uğurda ortaya koyduğu eserlerinden birisi de Paris'i hiç görmeden sadece duydukları, dinledikleri ve okuduklarına dayanarak kaleme aldığı Paris'te Bir Türk adlı romanıdır. Eser incelendiği zaman, yazarın öncelikli amacının sadece Fransa'yı tanıtmak olmadığı; bunun yanında gönülden bağlı olduğu Osmanlı kültürünü de yabancılara anlatmayı amaçladığı dikkatlerden kaçmaz.

\section{Paris'te Bir Türk'ten Avrupa'da Bir Cevelan'a}

Ahmet Mithat Efendi, Paris 'te Bir Türk romanını tamamen kadınlardan oluşan kahramanlar üzerine kurar ve kendinin bir timsali olan Nasuh dışında dikkati çeken erkek kahraman yok gibidir. Bütün erkekler Nasuh Efendi'nin bilgisi, görgüsü, centilmenliği, olaylara müdahale etmedeki soğukkanlılı̆g 1 ve entelektüel birikimi karşısında adeta sönük kalırlar. Roman boyunca parlayan bir yıldız vardır o da Nasuh'un kendisidir. Erkek karakterlerin hemen hemen hepsi güçlü bir kişiliğe sahip olan Nasuh'un himmetine muhtaçtır; çözülecek bütün işlerinde, tartışmaların mantıklıca sonlandırılmasında hatta sevdikleri kadınların gönüllerine giden yollarda hep Nasuh'un kudretli dokunuşlarına ihtiyaç duyarlar. Adeta bir roman kahramanı değil de masallardan, destanlardan fırlayıp gelmiş insanüstü bir varlık gibi roman boyunca okuyucunun karşısından hiç gitmeyen Nasuh, Ahmet Mithat'ın özlemini duyduğu, olmak istediği, hayalini kurduğu bir karakter abidesidir sanki.

4 Geniş bilgi için bkz. Dayanç, M. "Bir Yenileşme Dönemi Aydını Olarak Ahmet Mithat Efendi”, Türk Dili ve Edebiyatı Dergisi, Cilt/Sayı: XLVII. s. 81-96; Dayanç, M. (2012), "Ahmet Mithat Efendi ve Üss-i İnkılap Üzerine”, Türkish studies International Periodical Fort he Languages, Literature and History of Türkish or Turkic (Prof. Dr. Filiz Kılıç Armağanı), Sayı: 7/1, s. 837-847) 
Etrafındaki insanların onun bilgisine, görgüsüne, zarafetine hayran olmamaları ve yapılan tüm tartışmalardan muzaffer çıkmaması görülmüş bir şey değildir. Avrupalılar dâhil onun Avrupa sanatına, edebiyatına, tarihine, kültürüne vukufiyetine şaşırmamaları imkânsızdır; hatta böyle donanımlı bir karakterin Türk olabileceğine ihtimal dahi vermezler. Özellikle kadınların roman boyunca vazgeçemeyeceği tek erkek kahramanlarıdır Nasuh Efendi, Bütün eğlencelerde, gece toplantılarında onu görmek isterler, nazarları hep onun üzerindedir. Herkes onun kavalyeleri olmasını ister ama o kolay kolay kimseye böyle bir lütufta bulunmaz. Roman boyunca Şarklılarda pek rastlanılmayacak bir soğukkanlılıkla bütün iltifatları, davetkâr ve işveli bakışları bertaraf etmekte mahirdir. Etrafındaki/gecelerdeki kadınların kalbi onun için çarpmaktadır ama o hepsine üsten bakmayı bilir; hatta yatağına kadar gelen Fransız asilzadeye sırtını dönebilecek derecede de nefsine hâkim bir irade abidesidir. Tıpkı günümüzde çoğu tarihi Türk filmlerinde cesurca savaşarak Batı'yı dize getiren sinema kahramanları gibi; sanki yazar da Batı karşısında ezilmiş, küçülmüş, özgüvenini kaybetmiş, çaresiz bir İmparatorluğun onurunu kurtarma görevini Nasuh'un omuzlarına yüklemiş gibidir:

“Ahmet Mithat Efendi'nin, konusu Türkiye'de geçen romanlardaki tiplerle, Avrupa'da geçen vak'aların kahramanları arasında mahiyet farkı yoksa da derece farkı vardır. Türkiye'de geçen romanlarda alafranga ve milli tiplerin çatışmasına mukabil Avrupa'daki Osmanlıları Türk, İslam ve Doğu medeniyetinin temsilcisi ve müdavimi olarak görürüz. Bunlar, 1889 da Stockholm Şarkiyatçılar Kongresi'ne giden ve bir kısım Avrupa şehirlerini dolaşan muharririn kendisi gibi birer medeniyet misyoneridirler. Şarkın asalet, necabet ve mürüvvetini, Islam'ın ahlak ve faziletini, Türk'ün kahramanlık ve fedakârlığını Avrupa'ya tanıtmak için kendilerini adamış birer havari gibidirler" (Okay, 2008: 449).

Sadece kokteyllerde, eğlencelerde değil; biten eğlencelerin devamındaki sohbetlerde bile Nasuh'ten hiç vazgeçilmez:

“Açıktan açı̆̆a söyleyeyim Mönsieur Nasuh! Gönlüm sizin musahabe ve muhazaranızdan pek hoşlandı. Zira bir kere başka ecnebiler gibi .... Miskin demek hatta mahcup diyelim....mahcup değilsiniz. Kezalik başka ecnebiler gibi ifrat derecede açık da değilsiniz. Şensiniz! Şatırsınız! Zekisiniz! Tarihi pek güzel mütalaa 
etmişsiniz! Tarihi sizin kadar güzel mütalaa edenler mutlaka feylesof olurlar! Hasılı sizden gönlüm pek hoşlandl. Hatta bu akşam familyaca hep sizin hakkınızda söz söyleştik. Zevcem beni tasdik eyledi. Baldızım dahi peyrev oldu!’” (PBT: 132).

Ahmet Mithat Efendi, tıpkı romanındaki ana kahraman gibi kendisi de Cevelan'ında kadınlardan uzak değildir. Bu gezinin ilgi çekici yanlarından birisi yazarın Stockholm'deki kongrede tanıştığ1 Madam Gülnar'la olan dostluğu ve Gülnar'ın farklı kişiliğidir. Dillere karşı özel ilgi besleyen ve birçok dili rahatlıkla konuşabilen Gülnar, Osmanlıcasının temelini Kazan civarındaki Tatarlardan öğrenir. Petersburg'daki Osmanlı sefaretinde ve savaş zamanında esir düşen Osmanlı askerleriyle kurduğu ilişkilerle daha sonra da tanıştığı İstanbullu bir Ermeni muallim sayesinde Osmanlıcasını hayli yüksek bir seviyeye ulaştırır. Kırk yaşına henüz ulaşmamış böyle bir kadının bunca dil biliyor olması, yazarın yeterince ilgisini çekmişken, bir de piyano çalması, resim ve müzikte de hayli yetkin olması, ona olan ilgiyi daha da arttırır. Gülnar'ın Osmanlıya ve kültürüne ilgisi, kartvizitinin Osmanlıca hazırlanmasına; ev yaşantısının bile Osmanlı kültürüne göre dizayn edilmesine kadar varır:

"Ben Osmanlıların gerek lisanlarına ve gerek ahlaklarına gayet muhibbim. Kendi hanemde ekseriya alaturka elbise telebbüs ederim. Çocuklarıma fes giydiririm. İkametgâhıma teşrifle beni memnun edersiniz, bu yolda yaptırılmış olan fotoğrafları da size irae eylerim" (Cevelan, 2015:174).

Madam Gülnar'la kurulan dostluk kongre ve Avrupa yolculuğu boyunca epeyce ilerler. Gülnar, Ahmet Mithat Efendi için kültürüne, adetlerine, geleneklerine yabancı olduğu bu uzak diyarlarda, adeta kılavuz gibidir. Yazarın yanlış giyinip geldiği bir davette, kıyafetlerini hemen değiştirmesi için hayli 1srarcı olan Gülnar, romandaki kadın kahramanlar gibi Osmanlı centilmeninden sitayişle bahsederken onda en ufak bir eksikliğin gözükmesine de gönlü razı olmaz:

“...Pek çok kimselerin nazar-ı dikkati sizin üzerinizdedir. Bir Avrupalıda ufak tefek kusur görülse ilişmezler ama sizde görülecek en küçük kusurları bile izam ederler. Şimdiye kadar hiçbir kusurunuz görülmediğinden muvaffakiyetiniz arttıkça artıyor. ... Rica ederim ve size nasihat veririm ki üşenmeyip gidiniz. Sivil kıyafetlerinizi giyip nişan ve madalyalarınızı takınız." (Cevelan, 2015:174). 
Şarkiyatçılar Kongresinden sonra önemli şehirler ziyaret edilerek, molalar verilerek Paris'e doğru yapılan uzun tren yolculuklarında Osmanlı gezgini, hiç şikâyetçi değildir halinden. Çünkü yanında bilgili, kültürlü ve geçtikleri ülkelerin dillerini de çok iyi bilen, ona, Osmanlının en yakın komşularından biri olan Rusya hakkında geniş teferruatlar sunan "kamil insan" Madam Gülnar vardır:

"Arkadaş ne kadar fazıl olursa bu zevkin, bu lezzetin derecesi o nispette artar. Hamdolsun arkadaşım bir nazik kadın olmakla beraber fazl u kemali de işte böyle kendisiyle birlikte geçirdiğim zamanlart israftan addettirmeyecek ve zevkini, lezzetini arttırdıkça arttıracak derecelere varmış bir insan-ı kâmildi" (Cevelan, 2015:475).

Madam Gülnar'ın ilmine, zarafetine, ince sanat zevkine, tanıştığı ilk günden itibaren hayran olan yazar, yolculuk boyunca, onun gezi planlarına itiraz etmeksizin uyar ve sürekli birlikte gezer. Yalnız birçok yönden birbirleriyle güzel bir uyum içerisinde olan iki dostun uyuşamadığı bir konu vardır. O da Gülnar'ın geceleri çok geç yatıp, oldukça da geç kalkması, gezilere isteksiz olması, bazen tembellik yapıp otelindeki odasından hiç çıkmaması; buna karşın Ahmet Mithat Efendi'nin az uyuması, erkenciliği, dinçliği ve yeni yerleri görmedeki aşırı istekli ve heyecanlı olmasıdır.

Gülnar'la Paris'teki son günlerinde, iki kafadar, yeniden şehir turu yaparak Paris' in en güzel yerinde, nezih bir akşam yemeğiyle süslerler, bu duygusal anlarını. Gezi boyunca, birbirleriyle iyi anlaşan iki dost, anılarını yâd ederek, uzun bir gecenin içerisine dalarlar ve tabiî ki böyle bir veda akşamının derece-i kıymetini daha da arttracak olmazsa olmazı da birbirlerine büyük değer veren dostların veda gözyaşları olur:

"ikimiz dahi itiraf ve teslim ettik ki şu müddet zarfinda hiçbir dakikamız boş ve menfaatsiz geçmemiştir. Bunda yekdiğerimizle hamiyane, mahmiyane, mürşidane, müsterşidane hüsn-i imtizacın semeresi olduğunu bil-itiraf birbirimize teşekkür ettik ki gayet safiyane ve mütehassisane birkaç damla gözyaşlar da bu itirafattaki halisiyetimizin şahitleri oldular" (Cevelan, 2015:781).

Paris'teki son gecelerinde, otelde uzun bir sohbete başlarlar, Gülnar, Osmanlı ile Rusların komşulukları üzerine fikirlerini beyan eder. Ona göre; 
Osmanlı ile Ruslar birbirlerine çok yakın iki kapı komşu olmalarına rağmen, birbirleriyle edebiyat ve sanatta, fikir alışverişinde bulunmak yerine, her ikisi de Batının etkisinde ve onların yeni fikirlerine açık bir tavır içerisindedir. Gülnar, bunun doğru olmadığına inandığı için de Osmanlı'nın önemli edebi eserlerini Rusçaya; Rusların önemli edebi eserlerini de Türkçeye kazandırma düşüncesindedir.

Cevelan yazarı, bu (anne-kız) Rus dostlarına o kadar vefalıdır ki, hizmet etmekten zevk aldığını özellikle belirttiği Gülnar'a karşı centilmenliği, en üst safhadadır. Önce onların bütün eşyalarını istasyona taşır ve dostları Paris’ten ayrılmadan, kendisi de ayrılmaz. Madam Gülnar'la annesini yolcu ettikten sonra da istasyonda, yalnız başına treninin gelme vaktini beklemeye koyulur.

Yazar, Cevelan'da yolcu ettiği Gülnar'ın yokluğunun hüznü ile ülkesine dönmek zorundayken; Paris 'te Bir Türk romanında, ana karakter eli boş olarak değil; kendisiyle uyumlu bir eş olmaya karara vermiş, dinini de sevdiği adam için değiştirmeyi göze almış güzel Mademoiselle Virginie ile döner. Ancak Gülnar, farklı tarihlerde İstanbul'a gelerek hem dostluklarının devam etmesine hem de Rus-Osmanlı kültürlerinin birbirlerini daha yakından tanımalarına katk1da bulunur ${ }^{5}$.

Hem seyahatnamede hem romanda müellifin zihnini meşgul eden konulardan biri de Avrupa'nın Osmanlı dünyasını yanlış tanımasıdır. Bunun müsebbiplerinin ise yaptıkları işleri eğlenceli hale getirerek daha fazla ilgiyi üzerlerine çekmeyi amaçlayan ressamlar ve seyahatname yazarları olduğu iddia edilir. Yazar her firsatta bu yanlışlıklardan duyduğu rahatsızlığı dile getirir. Roman kahramanı Nasuh Efendi de etrafındakilerle Osmanlı ve İstanbul imajını düzeltmek için uzun tartışmalara girmekten çekinmez. Zaman içerisinde Avrupa'yla yakın temaslar içerisinde bulunan İmparatorlukta ve İstanbul'da birçok köklü gelişmelerin yaşandığını kuvvetle iddia eder (PBT, 2000: 25-30).

Gideceği Avrupa şehirlerinin önceden rehber kitaplarını elde etmek ve onları inceleyerek işine yarayacak notlar almak, Cevelan yazarının dikkat çeken özelliklerindendir. Böylece ilk defa bulunduğu Avrupa şehirlerinde hiç zaman kaybetmeden daha önce buralarda bulunmuş gibi rahat gezme şansına sahip 
olur. Seyahatnamesinde rehber kitaplarının yardımıyla sabahın erken saatlerinde rahatça gezebildiği Paris'i, görmeden yazdığı roman kahramanına da rahatça dolaştırır yine o kitapların kılavuzluğu sayesinde. Hatta yazar, Paris'i haritalar ve rehber kitaplar aracılığı ile o kadar güzel hafızasına nakşetmiştir ki çoğu Parislinin bile kendisi kadar bu şehri bilemeyeceği/tanıyamayacă̆ iddiasındadır:

"Bu kadar seyahati bahusus Nasuh'un dikkati kadar bir dikkatle eden zatın Paris havalisince bir hayli malumat alacağı şüphesiz olup, Nasuh ise gözüyle gördüğ̈̈ yerlerden maada mahsusen mubayaa etmiş olduğu Paris havalisi haritasını dahi ol kadar ezber etmişti ki, bir Parisli, hem de olur olmaz Parisli kadar değil, memleketini ve havalisini en ala taniyan Parisli kadar etraf ve civarı dahi tanımış ve öğrenmişti. Binaenaleyh birkaç güne kadar meşguliyeti Vincennes ve Saint-German ormanlart gibi Paris havalisinin en mutena yerlerini kaleme almaktan ibaret kalmış ve her yazdiğı bir rağbet-i mahsusaya mazhar olduğu gibi, bu bendleri her yazdiğından ziyade şayan-1 itibar görülmüştür”, (PBT, 2000: 245-246).

Ahmet Mithat Efendi, bulduğu her firsatta, Osmanlı centilmenin yabancılar tarafından takdir toplayabilecek özelliklerini öne çıkarmaya çalışır. Özellikle her iki eserinde de hem kendisinin hem roman kahramanı Nasuh'un, mecbur kaldıkları zaman ne kadar cesur, gözü kara ve çevresindekilere iyilik etmekten bir an için bile tereddüt etmeyen kişilikler olduklarına şahit olunur. Vapurda bayılan bir kıza etraftaki insanlar ilgisiz kalırken ilk müdahaleyi hiç düşünmeden Cevelan yazarı yapar. Paris’te Bir Türk romanında ise atıyla göle düşüp boğulma tehlikesi geçiren İngiliz’i çevredekiler eğlenceli kahkahalarla seyrederken, sadece Nasuh, elbiselerinin berbat bir hale geleceğini bile düşünmeden göle atılır ve perişan adamı kurtarır (PBT, 2000:247-248).

\section{Yükselen Medeniyet Karşısında İki Osmanlı: Nasuh/Ahmet Mithat Efendi}

19. asrın başından itibaren Avrupa medeniyeti, Şarklı gözleri kamaştıracak ve etkisi altına alabilecek bir seviyededir. Özellikle ahlak, din, aile, yaşayış tarzı bakımından, lehte/aleyhte olan insanların fikri çatışmaları ile bir mukavemet ve mücadele ile karşılaşırsa da kültürel alanda ciddi bir dirençle karşılaşmadan 
Doğu'nun dünyasına kolayca girebilir. Ahmet Mithat Efendi'nin Batı medeniyeti ve kültürü karşısındaki tavrı ise onu kompleksiz bir şekilde tanıyarak, Osmanlı dünyasına tanitabilmektir (Okay, 2008:351-354). Bunu yaparken de durduğu taraf hep kendi kültür bölgesidir. 'Mithat Efendi, bir medeniyet buhranının çocuğu olduğunu hiçbir zaman unutmaz. İslamiyet'i Hıristiyanlığa karşı müdafaa için 'Müdafaa ve Mukabele serisini yazan muharririmiz hemen her eserinde bu buhrana döner. O, Hıristiyan dünyası ve Avrupa ahlakı karşısında daima saf ve Avrupa kültürüyle muvazeneli şekilde aydınlanmış yerli ahlakın ve örfün müdafii olacaktır" (Tanpinar, 1985:472).

İstanbul'dan Gamboçya vapuruyla yola çıkan Ahmet Mithat Efendi'nin ana amac1; Avrupa'da gördüğü iyi/kötü her şeyi tarafsız bir şekilde ele alarak Avrupa'nın terakkiyatı hakkında bir fikre sahip olmak, insan aklını hayretler içerisinde bırakacak kadar maddi alanda ilerlemiş olan bu diyarları, bir anatomi uzmanı gibi masaya yatırarak bütün uzuvlarını tek tek derinlemesine incelemektir. Yazar, Avrupa'nın ilerlemesini; maddi ve manevi ilerlemeler olarak ikiye ayırır. Manevi ilerlemelerinin hiçbir yönünü beğenmemekle birlikte; maddi ilerlemelerinin hemen hemen bütün yönlerini beğenir, özellikle de teknik ve makinelerle ilgili olan terakkiyatı ${ }^{6}$. Avrupa'nın sokaklarının düzeni, binalarının büyüklüğü, zenginliği, güzelliği, caddelerinin genişliği ve temizliği onu makinelerdeki terakki kadar etkilemez; çünkü onlar kadar olmasa da İstanbul binalarılya, çarşılarıyla, hamamlarıyla, camileriyle, minareleriyle güzel bir şehirdir. İyi kötü Avrupa şehirleriyle kıyas edilebilir. İstanbul'un binalarının büyük bir bölümün ahşap olması hasebiyle belli aralıklarla çıkan yangınlar sonucu kül olmasaydı, İstanbul, güzel binalar bakımından da daha zengin olabilirdi. Bu şehirleri kıyaslamada yazarı, İstanbul lehine mutlu eden bir özellik de; Avrupa şehirlerinin aksine, İstanbul halkının büyük bir oranının kendi hanelerinde ikamet ediyor olmasıdır. Avrupa'da ise insanların büyük bir bölümü kiracıdır. Bu tür tesellilerle, kıyaslarla, manevi yönden çok sağlam olan yapıyla, kendini mutlu hisseden Ahmet Mithat Efendi, teknik alanda, onu mutlu edecek Osmanlı diyarından tek bir örnek bile gösteremez.

6 Orhan Okay, Ahmed Mithat Efendi’nin Batı medeniyetine - özellikle de onların teknik alanlardaki ilerlemelerineyaklaşımı ile onun sevgi ile bağlı olduğu Sultan II. Abdülhamid'in yaklaşımı arasında hiçbir farkın olmadığını belirtir. (Orhan Okay, Batı Medeniyeti Karşısında Ahmed Mithat Efendi, İstanbul, 2008, s. 30-31.) 
Yine bir akşam, otel lobisinde başlayan Şark-Garp karşılaştırılmasında Madam Gülnar ve annesine, Ahmet Mithat Efendi, sonunda onların da fikirlerini kabullenmek zorunda kalacağı, çok uzun bir nutuk irad eyler. Ona göre:

Insanların mutluluğu maddi ilerlemelerde değil; săglam bir maneviyat içerisinde yaşayabilmektedir. Başarılı bir ilerleme hamlesiyle başı dönen Avrupa, maneviyatının büyük bir kısmını kaybetmiştir. İnsanların en fazla mutlu oldukları yer evleri, aileleridir, çocuklarıyla birlikte oldukları anlard $\iota r$. Ancak Paris halkının bir kısmı terakkiyle birlikte bunların tümünden mahrumdur. Onların oturdukları ev, kullandıkları eşyalar kendilerinin olmak yerine kiradır. Çocuklarıyla birlikte yaşamayı ise bu halk adeta unutmuştur. Biraz zengin olanlar çocuklarını hemen doğumdan sonra bir sütanneye emanet etmekte; fakir olanlarsa karı-koca çalıştıkları için çocuklarını bir bakıcıya teslim etmek zorunda kalmaktadırlar. Akrabalık bağları da pek olmadığı için buralarda çocuklar bir aile sıcaklığı içerisinde büyümekten uzaktır. Aileler zamanlarını daha çok dışarıda geçirdikleri ve yemeklerini de dışarıda yedikleri için bir ev halleri de kalmamıştır. Halkın ev yaşamlarını öğrenmek isteyen bir kişinin bu ortamda böyle bilgilere ulaşması da artık çok zordur. Ona kaynaklık edecek tek veri büyük Fransız romancıların kaleminden çıkan eşsiz romanlardır; çünkü ev yaşamları sadece romanların tozlu sayfaları arasında kalmıştır.

Sanayileşmeyle birlikte halkta din duygusu yok olmaya başlamış, bütün kutsal değerlerden uzak kendilerini alabildiğine özgür hisseden bir toplum ortaya çıkmaya başlamıştır. Bunun sonucu olarak Paris’te doğan çocukların üçte biri gayr-1 meşru olarak dünyaya gelmektedir. Anneden, babadan, kardeşten, akrabadan uzak yetişen bu çocuklardan nasıl bir vatan sevgisi beklenebilir, vatan yolunda ne gibi fedakârlıklar beklenebilir? Biz Doğuluların en büyük eksiği maddi yönden terakki gösteremeyişimizdir ama manevi yönden bütün kurumlarımız aile yapımız sapasağlam durmaktadır. Biz bir gün mutlaka maddi yönden istenilen seviyelere ulaşacağızdır ama Batı'nın bu kadar yozlaştıktan sonra tekrar manevi değerlerine dönebilmeleri artık çok zordur ${ }^{7}$.

7 Ahmet Mithat Efendi hemen hemen fikr-i sabiti olan yukarıdaki görüşlerini Avrupa seyahati boyunca bulduğu her ortamda ortaya koymaya çalışır. Daha önce uzun tren yolculuklarında Madam Gülnar’a anlattı̆̆ı bu görüşlerini onun annesine de uzun uzadiya izahat etmekten mutlu olur. (daha fazla bilgi için bkz. Ahmed Mithat, Avrupa'da Bir Cevelan, (2015) s. 765-772). 
Avrupa cevelanının son noktalarından olan Viyana'da, Osmanlı sefiri Sadullah Paşa ile de Avrupa'nın terakkisi ve Osmanlının bu terakkideki yeri üzerine uzun konuşmalar yaparlar. Sadullah Paşa'nın da kendisiyle aynı görüşte olduğunu göstererek aslında Ahmet Mithat, devletle görüşlerinin aynı doğrultuda olduğunu, hatta daha da ileri giderek Sultan Abdülhamit'le Avrupa medeniyeti konusunda görüşlerinin örtüştüğünü gün yüzüne çıkarmaya çalışır. Onlara göre Osmanlı aydını, Avrupa medeniyetindeki büyük ilerlemeleri, gerçek anlamıyla inceleyip analiz etmek yerine, bir kısmı onları körü körüne destekleme; bir kısmı da onların karşısında olma yolunu tercih eder. Oysaki Avrupa'nın bu terakkisi, yansız bir şekilde ele alınıp, incelenip, duygusallıktan uzak bir şekilde halka tanıtılmalıdır. Avrupa'nın maddi ilerlemesi denildiği zaman da sadece güzel binaları, caddeleri, yaşam tarzları akla gelmemelidir. Bunların yanında tiyatroları, bin bir çeşit tarihi değerleri içerisinde barındıran kütüphaneleri, müzeleri, sanat eserleri de hatırlanmalıdır. Bu tür ilerlemeler ise Osmanlıda hemen hemen yok gibidir. Bu seviyeye gelebilmek için çalışmalı hem de çok çalışmalıdır (Cevelan, 2015:1000-1001).

Maddi terakkinin hep yanında olan A. Mithat Efendi, seyahati boyunca hiç sıcak bakmadığı Avrupa'nın manevi durumuna, Cevelan 'ının son sayfasındaki değerlendirmelerinde de soğuktur, onların manevi yöndeki gelişmelerine meyletmenin eski medeniyetin ve İslamiyet'in Osmanlıda oluşturduğu güzel hasletleri yok edeceğine inanır:

“.... bizim için Avrupa'nın terakkiyat-l maneviyesini arzu eylemek medeniyet-i kadimemizin ve diyanet-i Íslamiyemizin bizde peyda eylediği maneviyatı feda demek olacă̆ından buna vicdanımı bir veçhile rıza gösteremez. Zira Avrupa'nın maneviyatı ekseriyet üzere esas-ı ma'yubeye mübteni olduğundan onlar memduhiyetçe bizim maneviyatımıza kıyas bile kabul edemez (Cevelan, 2015:1001).

Ahmet Mithat'ın gerçekten özlediği ideal toplum; maddede inanılmaz derecede ileri gitmiş Batı ile maddi terakkiyi özellikle son asırlarda ihmal ederek, manevi yönden gelişen Doğu'nun birleşmesinden doğabilecek olan toplumdur (Okay, 2008:52-53). 
Çoğu Tanzimat yazarı gibi Ahmet Mithat, Paris'te Bir Türk romanında sürekli Batı toplumu ile Osmanlı toplumunu karşılaştırma ihtiyacı duyacaktır. Roman kahramanı Nasuh Efendi'nin roman boyunca birincil görevi -tıpk1 Cevelan'da Ahmet Mithat Efendi’nin yaptığı gibi- içinde yetiştiği toplumunun gönüllü savunucusu olmaktır. Batı'nın maddi yönden ilerlemişliğine rağmen Osmanlı dünyasının manevi yönden, yönetim ve yaşantı bakımından birçok güzel yönlerini etrafındakilere ikna edici bir üslupla dile getirir:

...Işste bizim memlekette hükümet-i cumhuriyyet olmayıp hükümet-i sultaniyye vardır. Bununla beraber şu dediğiniz müsavat da vardır. Bir sadrazamın oğlu sadrazam olmaya layık değil ise, mahza zadelikten dolayı hiçbir iddiaya kıyam edemez. Öte taraftan bir hamalın oğlu liyakat kazanır sadrazam olur. Demek isterim ki bu nimet-i müsavat dahi yalnız hükumet-i cumhuriyyede bulunmaz...(PBT, 2000:303)

\section{Sonuç}

Yakın komşuları olan Avrupa'yı geç de olsa tanıma gayreti içerisine giren ve bir medeniyet değiştirme sürecindeki Osmanlı toplumu için seyahatnameler/romanlar bu yolda işlevsel roller üstlenir. Seyahatnamelerle ötekinin farklı dünyası gözler önüne serilerek iki dünya arasındaki gelişmişlik uçurumunun ne denli büyük olduğunun idrak edilmesi, bu uğurda bir gayretin uyanması amaçlanırken; romanlarla, kurmacanın vermiş olduğu geniş bir hayal dünyasının desteği de alınarak, istenilen amacın daha da ilerilere taşınmasına gayret edilir.

Yaptığ̀ bütün sanatsal çalışmalarda/girişimlerde toplumsal faydaları önceleyen Ahmet Mithat Efendi, Özellikle romanları ile topluma yeni bir dünyanın kapılarını açmanın gayret ve azmi içerisindedir. Bu uğurda elindeki bütün kaynakları sanatçı titizliğinin seçiciliğini de bir tarafa bırakarak kullanmayı amaçlar, sanatkârlı̆̆ının muhalifleri tarafından acımasızca eleştirilebileceğini aklına bile getirmeden. Avrupa'ya açılan birer pencere olması amacıyla yazılan Paris'te Bir Türk romanı ile Avrupa'da Bir Cevelan adlı seyahatnamesi de toplumsal fayda göz önünde bulundurularak kaleme alınmış iki eseridir muharririn. Paris'i görmeden yazdığı romanı ile Paris'i adım adım dolaşarak vücuda getirdiği seyahatnamesi arasında benzerlikler dikkate değerdir. 
Roman kahramanı Nasuh ile seyahatname yazarı Ahmet Mithat Efendi arasında benzerlikler için adeta Nasuh Efendi'ye Ahmet Mithat'in tıpatıp aynısıdır denilse mübalağa yapılmış olmaz; sadece romanın kurmaca dünyasının sağladığı rahatlıkla kahramanın oldukça mükemmelleştirildiğinin akıldan uzak tutulmaması şartı ile. Tipkı Cevelan'daki Ahmet Mithat gibi Nasuh da etrafindakilerle münazara etmekten hiç kaçınmaz ve bu sohbetlerde o da Şark/Osmanlı kültürünün y1lmaz bir savunucusudur. Okuyucunun aklına bazen 'Nasuh'un Paris'e gidişindeki birincil gayenin maddi yönden ilerlemiş bir kültürden ülkesi için yeni/faydalı olan şeyleri yüklenip getirmek mi; yoksa kendi kültürünü onlara usanmaksızın anlatmak mı olduğu" sorusunun gelmesi de kaçınılmaz olur. Bunun yanında o da tıpkı Cevelan yazarı gibi sabahları erkenden kalkmaktan, rehber kitapların kılavuzluğunda Paris'i sokak sokak gezmekten zevk alır ve bu gezilerinde bir şekilde etraflarında sohbetlerinden, onlarla birlikte olmaktan mutlu oldukları kadın veya kadınlar vardır. 


\section{Kaynakça}

Ahmet Mithat Efendi (2015), Avrupa'da Bir Cevelan, (Haz. N. Arzu Pala), Dergâh Yayınları, İstanbul.

Ahmet Mithat Efendi (2000), Paris 'te Bir Türk, (Haz. Erol Ülgen) Türk Dil Kurumu, Ankara.

And1, M. Fatih (1996), Bir Osmanlı Bürokratının Avrupa İzlenimleri, Kitabevi Yayınları, İstanbul.

Asiltürk, Baki (2000), Osmanlı Seyyahlarının Gözüyle Avrupa, Kaknüs Yayınları, İstanbul.

Balcı, Yunus (2010), “Türk Romanında Aydın Sorunu”, Türk Romanı Özel Sayısı, Hece, S.53/54/55. Ankara,

Bardakçı, Murat (2015), Enver, Türkiye İş Bankası Kültür Yayınları, İstanbul.

Belge, Murat (1994), Edebiyat Üstüne Yazılar, YKY, İstanbul.

Berman, Marshall (2017), Katı Olan Her Şey Buharlașıyor, İletişim Yayınları, İstanbul.

Dayanç, Muharrem (2012) "Bir Yenileşme Dönemi Aydını Olarak Ahmet Mithat Efendi”, Türk

Dili ve Edebiyatı Dergisi, Cilt/Say1: XLVII, s. 81-96.

Dayanç, Muharrem (2016), "Elçilikler”, Yeni Türk Edebiyatına Giriş, Anadolu Üniversitesi AÖFF Yayınları, Eskişehir.

Dayanç, Muharrem (2016), "Lale Devri”, Yeni Türk Edebiyatına Giriş, Anadolu Üniversitesi AÖFF Yayınları, Eskişehir.

Dayanç, Muharrem (2012), “Ahmet Mithat Efendi ve Üss-i İnk1lap Üzerine”, Türkish studies International Periodical For the Languages, Literature and History of Türkish or Turkic (Prof. Dr. Filiz Kılıç Armağanı), Sayı: 7/1, s. 837-847

Ecevit, Yıldız (2006), Türk Romanında Postmodernist Açılımlar, İletişim Yayınları, İstanbul.

Esen, Nüket (2014), Hikaye Anlatan Adam: Ahmet Mithat, İletişim Yayınları, İstanbul.

Findley, Carter V. (1999), Ahmed Mithat Efendi Avrupa'da, Tarih Vakf1 Yurt Yayınları, İstanbul. Gökçek, Fazıl (2012), Küllerinden Doğan Anka, Ahmet Mithat Efendi Üzerine Yazılar, Dergâh Yayınları, İstanbul.

Gürbilek, Nurdan (2017), "Erkek Yazar, Kadın Okur” Kadınlar Dile Düşünce, Edebiyat ve Toplumsal Cinsiyet, İletişim Yayınları, İstanbul.

Gürsoy Sökmen Müge - Başak Ertür (2008), Edward W. Said Anısına-Barbarları Beklerken, Metis Yayınları, İstanbul.

Hanioğlu, M. Şükrü, (1992), "Batılılaşma", TDİA, C. 5.

Hourani, Albert (1993), Islam in European Thought, Cambridge

Kabbani, Rana (1993), Avrupa'nın Doğu İmajı, Bağlam Yayınları, İstanbul.

Koçak, Ahmet (2013), Türk Romanında Avrupa, Kitabevi Yayınları, İstanbul.

Korkmaz, Ramazan (2012), Yeni Türk Edebiyatı El Kitabı, Grafiker Yayınları, İstanbul.

Lewis, Bernard (1988), Modern Türkiye'nin Doğuşu, TTK.

Moran, Berna (1987), Türk Romanına Eleştirel Bir Bakış, Ahmet Mithat tan A. H. Tanpınar 'a, 
İletişim Yayınları, İstanbul

Okay, Orhan (2008), Batı Medeniyeti Karşısında Ahmed Mithat Efendi, Dergâh Yayınları, İstanbul.

Ortaylı, İlber (2006), İmparatorluğun En Uzun Yüzyılı, Alkım Yayınları, İstanbul.

Ortaylı, İlber (2016), Osmanlı'ya Bakmak, Osmanlı Çağdaşlaşması, İnkılap yayınları, İstanbul. Özel, Mustafa, (2018), Roman Diliyle İktisat, Küre Yayınları, İstanbul.

Şirin, İbrahim (2000), Osmanlı Imgeleminde Avrupa, Lotus Yayınları, Ankara

Tanpınar, Ahmet Hamdi (1985), 19 uncu Asır Türk Edebiyatı Tarihi, Çağlayan Kitabevi, İstanbul.

Yağcığlu, Semiramis (2017), Roman Kahramanı ve Öznellik: Söylem İdeoloji ve Coğrafya, Komşu Yayınları, İstanbul.

Yirmisekiz Çelebi Mehmet Efendi (2017), Paris Sefaretnamesi, Haz. Abdullah Uçman, Dergâh Yayınları, İstanbul. 